\title{
GUILTY BUT MENTALLY ILL AND THE DEATH PENALTY: PUNISHMENT FULL OF SOUND AND FURY, SIGNIFYING NOTHING
}

\author{
VAN W. ELLIS \\ INTRODUCTION
}

On September 26, 1988, James Wilson entered Oakwood Elementary School brandishing a .22-caliber revolver. Within minutes, he killed two young children, wounded numerous others, and traumatized many for life. At trial, he was sentenced to death. Mr. Wilson was not insane at the time of his killing spree. It would seem, therefore, that he deserved harsh punishment for his actions. What if, however, Mr. Wilson explained that he simply could not help himself? What if we believed him? In fact, Mr. Wilson did offer this explanation, and the South Carolina courts did believe him. The South Carolina Supreme Court observed that Mr. Wilson "acted under an irresistible impulse at the time of his crime." Nevertheless, it affirmed his sentence of death. "James Wilson could not control his own worst impulses. Sometimes our judicial system has the same problem."2

The Eighth Amendment to the U.S. Constitution and its state counterparts stand as a bulwark against the imposition of cruel and unusual punishment. ${ }^{3}$ They prescribe parameters on punish-

1. State v. Wilson, 413 S.E.2d 19, 23 (S.C.), cert. denied, 113 S. Ct. 137 (1992).

2. It's Wrong to Kill the Mentally Ill, ATLANTA J. \& CONST., May 14, 1989, at D-6.

3. The Eighth Amendment to the U.S. Constitution provides: "Excessive bail shall not be required, nor excessive fines imposed, nor cruel and unusual punishments inflicted." U.S. CONST. amend. VIII. The Eighth Amendment itself prohibits the infliction of cruel and unusual punishment for federal crimes; the Due Process Clause of the Fourteenth Amendment similarly prohibits the states from extracting such punishment for state crimes. See Robinson v. California, 370 U.S. 660, 667 (1962). See generally Arthur E. Sutherland, Jr., Due Process and Cruel Punishment, 64 HARv. L. REv. 271 (1950) (discussing imcorporation of Eighth Amendment protections through the Fourteenth 
ment by mandating that the penalty imposed be adapted to the severity of the crime. ${ }^{4}$ Given that the death penalty is unique among punishments, ${ }^{5}$ the U.S. Supreme Court has determined that the imposition of such a severe and irrevocable penalty must be subjected to stringent standards. ${ }^{6}$

In recent years, many states, including South Carolina, have created potential Eighth Amendment difficulties by adding "guilty but mentally ill" to the list of possible verdicts in criminal cases. In State v. Wilson, ${ }^{7}$ the Supreme Court of South Carolina bulldozed through the landscape of the Eighth Amendment by upholding a capital sentence for an individual found to be guilty of murder but mentally ill. ${ }^{8}$ Under South Carolina law, to be convicted as guilty but mentally ill, the defendant must be found to have acted under an impulse that was irresistible. ${ }^{9}$ By imposing

Amendment).

4. See, e.g., Weems v. United States, 217 U.S. 349, 367, 382 (1910) (holding that the Eighth Amendment prohibits a sentence of cadena temporal, i.e., imprisonment that includes hard labor in chams and permanent civil disabilities, for the falsification of public documents).

5. Throughout most of American history, it has been assumed for constitutional purposes that the death penalty is a valid form of criminal punishment. This view was explicitly recognized in Trop v. Dulles, 356 U.S. 86 (1958), when the U.S. Supreme Court explained that "the death penalty has been employed throughout our history, and in a day when it is still widely accepted, it cannot be said to violate the constitutional concept of cruelty." Id. at 99. In 1972, however, a majority of the Supreme Court negated this assumption of constitutionality in Furman v. Georgia. 408 U.S. 238 (1972). Five Justices, each writing separately, held that the death penalty, as applied, was unconstitutional in light of the capricious application of capital punishment under a system that gave juries broad discretion in imposing punishments. See id. at 309-10 (Stewart, J., concurring).

Although some believed that Furman foreshadowed the abolition of the death penalty, Note, Cruel and Unusual Punishment, 86 HARv. L. REv. 76, 84-85 (1972), in 1976 the Court made clear that it was the manner in which capital punishment had been imposed, and not the penalty itself, that led to the decision in Furman. Gregg v. Georgia, 428 U.S. 153 (1976) (holding that the death penalty is not per se an unconstitutional punishinent); see also Jurek v. Texas, 428 U.S. 262 (1976); Proffitt v. Florida, 428 U.S. 242 (1976) (companion cases holding same).

6. Lockett v. Ohio, 438 U.S. 586, 605 (1978) (plurality opinion) ("Given that the imposition of death by public authority is so profoundly different from all other penalties, we cannot avoid the conclusion that an individualized decision is essential in capital cases."); see Coker v. Georgia, 433 U.S. 584, 592 (1977) (plurality opinion) (outlining Eighth Amendment restraints against excessive punishment).

7. 413 S.E.2d 19 (S.C.), cert. denied, 113 S. Ct. 137 (1992).

8. Id. at 29.

9. The law provided: "A defendant is guilty but mentally ill if, at the time of the commission of the act constituting the offense, ... . because of mental disease or defect he lacked sufficient capacity to conform his conduct to the requirements of the law." Act of May 16, 1984, No. 396, § 2(A), 1984 S.C. Acts 1785, 1786 (current version at S.C. 
capital punishment on such an individual, the courts of South Carolina have ignored the basic principle permeating Eighth Amendment analysis of capital punishment: there should be a direct correlation between the personal culpability of an individual and the punishment he receives. ${ }^{10}$

This Note begins with an examination of two Eighth Amendment constraints imposed on the application of capital punishment: proportionality and penological justification. Part I argues that these constraints require that the death penalty's application be limited to those instances in which the defendant has sufficient culpability. In order to demonstrate the way in which culpability analysis functions, Part II surveys some of its applications within the capital punishment context. In particular, this Part focuses on the effect of volitional impairment on culpability by examining two death penalty cases-Thompson $v$. Oklahoma, ${ }^{11}$ which involved a youth, and Penry v. Lynaugh, ${ }^{12}$ which involved a mentally retarded person. Part III details areas in which courts have applied the involuntariness doctrine as a bar to conviction. This Part also relates the involuntariness doctrine to the concept of volitional impairment in order to establish its position vis-à-vis the verdict of guilty but mentally ill. A step-by-step analysis of the label guilty but mentally ill is offered in Part IV. This Part argues that, if "guilty but mentally ill" connotes an irresistible impulse, a functional equivalent of an involuntary act is recognized. Accordingly, the recognition of an inability to control one's actions should result in a proscription against application of the death penalty. This Part also examines those instances in which the label of guilty but mentally ill implies lesser impairments that are, nonetheless, substantial. The Note concludes by arguing that the de jure recognition of volitional impairment embodied in the guilty but mentally ill verdict is incompatible with the Eighth Amendment's culpability requirement. As such, individuals who are convicted as guilty but mentally ill should not be eligible for the death penalty.

CODE ANN. § 17-24-20 (Law. Co-op. Supp. 1992)).

10. Penry v. Lynaugh, 492 U.S. 302, 319 (1989).

11. 487 U.S. 815 (1988).

12. 492 U.S. 302 (1989). 


\section{EIGHTH AMENDMENT CONSTRAINTS ON CAPITAL PUNISHMENT ${ }^{13}$}

\section{A. Proportionality and Penological Justification}

At its core, the Eighth Amendment prohibits punishment that is disproportionate to the severity of the crime ${ }^{14}$ and punishment that is without penological justification. ${ }^{15}$ In determining whether a punishment is disproportionate to the severity of the crime, Eighth Amendment analysis demands more than a superficial examination of the magnitude of the harm the crime caused. The Eighth Amendment requires an assessment of the defendant's uniqueness with regard "to his personal responsibility and moral guilt."16 This requirement mandates that a defendant be culpable at a level sufficient to justify capital punishment. When the presence of a particular factor reveals that a defendant has not reached this level, the sentence of death is disproportionate and, consequently, prohibited.

In addition to requiring that punishment not be grossly disproportionate to the culpability of the defendant, the Eighth Amendment also prohibits punishment that is without penological justification. The U.S. Supreme Court has recognized that the death penalty is penologically justified when it serves one of two goals: deterrence or retribution. ${ }^{17}$ Unless the execution of a defendant will advance one of these goals, the execution "is nothing

13. This Note focuses on the Eighth Amendment requirements of proportionality and penological justification for capital punishment and does not inquire into historically based forms of analysis or those centering on evolving standards of decency.

14. Gregg v. Georgia, 428 U.S. 153, 173 (1976).

15. Id. at 183.

16. Enmund v. Florida, 458 U.S. 782, 801 (1982) (stating that a defendant's "punishment must be tailored to his personal responsibility and moral guilt"); Eddings v. Oklahoma, 455 U.S. 104, 110 (1982) (noting "the law's effort to develop a system of capital punishment at once consistent and principled but also humane and sensible to the umiqueness of the individual").

17. Gregg, 428 U.S. at 183 . In Gregg, the Court also noted that incapacitation is a rationale that has been advanced as a penological justification. Id. at 183 n.28. Although incapacitation is a valid reason for imposing punishment and would undoubtedly "be served by execution[,] . . . in view of the availability of imprisonment as an alternative means of preventing the defendant from violating the law in the future, the death sentence would clearly be an excessive response." Spaziano v. Florida, 468 U.S. 447, 478 (1984) (Stevens, J., concurring in part and dissenting in part). Accordingly, incapacitation has not been incorporated into the culpability analysis. 
more than the purposeless and needless imposition of pain and suffering,' and hence an unconstitutional punishment."18

As to deterrence, in Skipper $v$. South Carolina, ${ }^{19}$ Justice Powell, joined by Chief Justice Burger and Justice Rehnquist, stated that "the death penalty has little deterrent force against defendants who have reduced capacity for considered choice."20 Indeed, the Supreme Court of Indiana stated the obvious when it said that the death penalty would not deter those defendants lacking the ability to conform their conduct to the law. ${ }^{21}$ Whereas the guilty but mentally ill defendants in Indiana presumably can be deterred since, under Indiana's statutory definition of "mentally ill," they do not necessarily lack the ability to conform their actions to the requirements of the law, such a "defendant under South Carolina law[] has in essence been found to have acted under an irresistible impulse."23 Despite the South Carolina Supreme Court's explicit recognition that one goal of the penal system is "to deter those who can be deterred from acting unreasonably,"24 the court conspicuously omitted any reference to the deterrence value of Mr. Wilson's death sentence. Instead, the court based its justification of the sentence on the retribution rationale. ${ }^{25}$ Accordingly, the courts have recognized that if there is a penological justification for the execution of guilty but mentally ill defendants who act under an irresistible impulse, it must reside in the retribution rationale.

Although recognizing retribution as an alternative justification for the death penalty, the U.S. Supreme Court disfavors retribution as the sole basis for its imposition. ${ }^{26}$ Accordingly, this justi-

18. Enmund, 458 U.S. at 798 (quoting Coker v. Georgia, 433 U.S. 584, 592 (1977)).

19. 476 U.S. 1 (1986).

20. Id. at 13 (Powell, J., concurring) (citing Eddings, 455 U.S. at 115 n.11).

21. See Harris v. State, 499 N.E.2d 723, 727 (Ind. 1986), cert. denied, 482 U.S. 909 (1987).

22. See IND. CODE ANN. § 35-36-1-1 (Burns 1985) ("Mentally ill' means having a psychiatric disorder which substantially disturbs a person's thinking, feeling, or behavior and impairs the person's ability to function ....") (einphasis added).

23. State v. Wilson, 413 S.E.2d 19, 23 (S.C.), cert. denied, 113 S. Ct. 137 (1992). In contrast to the Indiana statute, the South Carolina statute provides that the guilty but mentally ill defendant is one who lacks the capacity to conform his conduct to the requirements of the law. See S.C. CODE ANN. $\$ 17-24-20$ (Law Co-op. Supp. 1992). For a discussion of the differences in state statutory definitions of guilty but mentally ill, see infra notes 107-08 and accompanying text.

24. Wilson, 413 S.E.2d at 24 (emphasis added).

25. Id. at 25 .

26. Gregg v. Georgia, 428 U.S. $153,183^{\circ}$ (1976) ("Retribution is no longer the domi- 
fication for the death penalty has been limited by the principle that retribution may only be exacted from those who are sufficiently culpable. ${ }^{27}$ As with disproportion analysis, culpability is determined through an examination of "the relevant facets of "the character and record of the individual offender." "2s

A death sentence will not survive Eighth Amendment scrutiny if it is either disproportionate to the severity of the crime or lacking in penological justification. Insofar as the defendant's culpability is the determinative issue for both the disproportion standard and the goal of retribution, culpability is ultimately dispositive for purposes of this analysis. ${ }^{29}$

\section{B. New Federalism Ensures the Lasting Vitality of the Culpability Analysis}

In recent years, some U.S. Supreme Court Justices have questioned whether there is, in fact, a culpability requirement inherent in the Eighth Amendment. In Thompson v. Oklahoma, ${ }^{30}$ Justice Scalia, in dissent, opined that the Eighth Amendment authorizes an analysis only as to whether the punishment in question was "forbidden under the original understanding of "cruel and unusual" " or forbidden as contrary to the "evolving standards of decency' of our national society." ${ }^{1}$ Just one year after making this statement, Justice Scalia, writing for the Court in Stanford $v$. Kentucky, ${ }^{32}$ again advocated an emasculation of culpability analy-

nant objective of the criminal law ....") (quoting Williams v. New York, 337 U.S. 241, 248 (1949)).

27. Tison v. Arizona, 481 U.S. 137, 149 (1987) ("The heart of the retribution rationale is that a criminal sentence must be directly related to the personal culpability of the criminal offender."). As Thomas Hobbes noted:

Revenge[], (that is, retribution of Evil for Evil,) ... without respect to the

Example, and profit to come, is a triumph, or glorying in the hurt of another, tending to no end; (for the End is alwayes somewhat to Come;) and glorying to no end, is vainglory, and contrary to reason; and to hurt without reason, tendeth to the introduction of Warre; which is against the Law of Nature; and is commonly stiled by the name of Cruelty.

Thomas HoBbes, LEviathan 210 (C.B. Macpherson ed., Penguin Books 1968) (1651).

28. Tison, 481 U.S. at 149 (quoting Woodson v. North Carolina, 428 U.S. 280, 304 (1976)).

29. This observation is true even if the penological justification for the imposition of capital punishment in a particular instance is deterrence, since the sentence still must satisfy the proportionality requirement, which is linked to culpability.

30. 487 U.S. 815 (1988).

31. Id. at 873 (Scalia, J., dissenting).

32. 492 U.S. 361 (1989). 
sis. ${ }^{33} \mathrm{He}$ called for an inquiry that focused merely on whether there was a historic or modern consensus forbidding the imposition of the death penalty on a particular class of defendants. ${ }^{34}$ Although such dicta may call into question the future of the Eighth Amendment's culpability analysis, ${ }^{35}$ it certainly does not determine the applicability of such analysis at the state level.

In many instances, Americans must learn to live with the Supreme Court's decisions, however wrong they believe those decisions to be because the Supreme Court often has the last word on legal matters. When determining whether application of the death penalty constitutes cruel and unusual punishment, however, it is not necessary to accept interpretations that are contrary to reason. As sovereign entities, states have the power to enact their own prohibitions against what they consider to be inhumane punishments. To mix metaphors, if the U.S. Supreme Court drops the ball on the issue of capital punishment, state courts must step up to the plate and make the hard decisions. ${ }^{36}$

Indeed, the Supreme Court of Delaware accepted this challenge when it determined that Article I, Section 11 of its constitution, ${ }^{37}$ independent of the Eighth Amendment to the U.S. Constitution, "demands that a death sentence be proportionate to a defendant's culpability and that it accomplish some legitimate penological end." 38 The Delaware Supreme Court accepted the

33. Id. at 378-80 (Scalia, J.) (plurality opinion). Justice Scalia was joined in this portion of his opinion by three other Justices.

34. Id. at 380 .

35. But see Coker v. Georgia, 433 U.S. 584, 591-92 (1977) (stating that the Court has "firmly embraced" the disproportion and penological justification modes of analysis as part of its determination that the death penalty is not per se unconstitutional).

36. The necessity to do so was well noted by John Chipman Gray:

[T] he difference between the judges and Sir Isaac [Newton] is that a mistake by

Sir Isaac in calculating the orbit of the earth would not send it spinning round the sun with an increased velocity; his answer to the problem vrould be simply wrong; while if the judges, in investigating the reasons on which the Law should be based, come to a wrong result, and give forth a rule which is discordant with the eternal verities, it -is none the less Law. The planet can safely neglect Sir Isaac Newton, but the inhabitants thereof have got to obey the assumed pernicious and immoral rules which the courts are laying down ....

John ChIPMan Gray, The NATURE and Sources of the LAw 101 (Roland Gray ed., 2d ed. 1921).

37. The Delaware Constitution of 1897 provides: "Excessive bail shall not be required, nor excessive fines imposed, nor cruel punishments inflicted; and in the construction of jails a proper regard shall be had to the health of prisoners." DEL. CONST. of 1897 , art. I, \& 11 .

38. Sanders v. State, 585 A.2d 117, 147 (Del. 1990). 
invitation offered by Justice Brennan in an influential article, wherein he observed that "the decisions of the Court are not, and should not be, dispositive of questions regarding rights guaranteed by counterpart provisions of state law." ${ }^{39}$ In fact, the U.S. Supreme Court explicitly recognized the force of Justice Brennan's statement when it noted that "[i]t is elementary that States are free to provide greater protections in their criminal justice system than the Federal Constitution requires." ${ }^{40}$ It is certainly possible that other states would follow Delaware's lead if the U.S. Supreme Court were to abandon the culpability analysis of the Eighth Amendment. Nearly every state has a constitutional provision that closely approximates the Eighth Amendment to the Federal Constitution. ${ }^{41}$ Many of these states could easily require a culpability analysis on independent state constitutional grounds. It is likely that other state courts would choose this route because of the severity of the penalty in question, ${ }^{42}$ the deeply ingrained nature of the concepts of proportionality ${ }^{43}$ and penological justification, and the popularity of new federalism. ${ }^{44}$ Given the severity and finality of the death penalty, judicial integrity would demand that state judges pursue an independent path if the U.S. Supreme Court were to eviscerate Eighth Amendment protections by dropping the culpability requirement.

39. William J. Brennan, Jr., State Constitutions and the Protection of Individual Rights, 90 HARv. L. REV. 489, 502 (1977).

40. California v. Ramos, 463 U.S. 992, 1013-14 (1983); see Cruzan v. Director, Mo. Dep't of Health, 497 U.S. 261, 277 (1990) ("State courts have available to them for decision a number of sources-[including] state constitutions ... - which are not available to us.").

41. See Sol Rubin, The LAw of Criminal Correction 423 (2d ed. 1973) (noting that nineteen states prohibit cruel or unusual punishment; twenty-two prohibit cruel and unusual punishment; and six prohibit only cruel punishment).

42. See, e.g., Rummel v. Estelle, 445 U.S. 263, 272 (1980) (stating that "a sentence of death differs in kind from any sentence of imprisonment, no matter how long").

43. The tenet that punishment must be proportionate to an individual's culpability is a bedrock of natural law theories. Saint Thomas Aquinas wrote that punishment "depends on the ability of the agent, because discipline should be adapted to each one according to his ability, taking also into aceount the ability of nature (for the same burdens should not be laid on children as on adults) ...." ST. THOMAS AQUINAS, The Summa Theologica, in 2 BASIC WRITINGS OF SAINT THOMAS AQUINAS 225, 786 (Anton C. Pegis ed., 1945).

44. See generally Robert B. Utter, State Constitutional Law, the United States Supreme Court, and Democratic Accountability: Is There a Crocodile in the Bathtub?, 64 WASH. L. REV. 19, 27 (1989) ("At last count more than 450 published state court opinions interpret state constitutions as going beyond federal constitutional guarantees."). 


\section{Culpability ANalysis as Applied to CAPITAL PUNISHMENT}

Although the U.S. Supreme Court has determined that the death penalty itself is not unconstitutional per se, it has used the culpability requirement inherent in the Eighth Amendment to proscribe the use of capital punishment in certain settings. The culpability requirement may operate to exclude the death penalty as a punishment option for entire categories of offenses ${ }^{45}$ or classes of people. ${ }^{46}$ In each instance, capital punishment is proscribed because the category of the offense or the class of defendants possesses insufficient culpability.

With respect to the category of the offense, the Court drew an important bright line around capital punishment soon after reinstating the death penalty in Gregg v. Georgia. In Coker $v$. Georgia, ${ }^{47}$ the Court determined that "a sentence of death is grossly disproportionate and excessive punishment for the crime of rape and is therefore forbidden by the Eighth Amendment as cruel and unusual punishment." 48 In drawing this line, the Court singled out the absence of the taking of human life as the factor that made rape ineligible for classification as a capital offense. ${ }^{49}$ Thus, the culpability requirement demands that a capital offense be defined by the result of unjustified human death. ${ }^{50}$

Eighth Amendment culpability analysis is not limited, however, to an examination of the categories of crimes that may be classified as death-eligible. ${ }^{51}$ The culpability standard also requires

45. See, e.g., Coker v. Georgia, 433 U.S. 584 (1977) (holding that it is unconstitutional to impose the death penalty against a defendant who rapes but does not kill).

46. Cf. Robinson v. California, 370 U.S. 660, 667 (1962) (holding that a state statute criminalizing the status of addiction to drugs violated the Eighth Amendment). The Robinson Court's holding that status itself may not be criminalized necessarily encompasses a prohibition on capital punishment for drug addiction.

47. 433 U.S. 584 (1977).

48. Id. at 592 .

49. Id. at 598 ("Rape is without doubt deserving of serious punishment; but in terms of moral depravity and of the injury to the person and to the public, it does not compare with murder, which does involve the unjustified taking of human life.").

50. But see The Supreme Court, 1976 Term, 91 HARV. L. REV. 70, 128 (1977) ("[S]ince treason, a crime against masses of people, may cause more aggregate harm than a single murder, the greater public injury may justify the imposition of the death penalty."); see also 4 WILLIAM BLACKSTONE, COMMENTARIES *24 ("[I]diots and lunatics are not chargeable for their own acts, if committed when under these incapacities: no, not even for treason itself.") (citation omitted).

51. See Woodson v. North Carolina, 428 U.S. 280,298 (1976) ("[I]ndividual culpabili- 
scrutiny of the individual defendant in question. ${ }^{52}$ The caselaw suggests that some individual traits may so diminish culpability that the death penalty is inappropriate for persons exhibiting these traits. ${ }^{53}$

When a trait predominates across an entire class and directly affects culpability, it is appropriate for the Court to consider drawing a bright line around the class. In Enmund v. Florida, ${ }^{54}$ for example, the Court examined whether an accomplice to murder could be sentenced to death on the basis of the felony murder doctrine. The Court noted that "[t]he focus must be on his [the defendant's] culpability, not on that of those who committed the [crime] and shot the victims."ss In focusing on the culpability of the non-triggerman in a felony murder, the Court identified two issues as bearing on whether such a defendant could be sufficiently culpable to receive the penalty of death: the defendant's actions and the defendant's mens rea. ${ }^{56}$ Based on the confluence of the defendant's non-triggerman status and his lack of intent to kill, the Court found that the defendant's culpability was too limited to allow the imposition of the death penalty. ${ }^{57}$ In so doing, the Court held that the culpability requirement of the Eighth Amendment barred a penalty of death when a defendant both lacked the intent to kill and did not actually kill. ${ }^{58}$

ty is not always measured by the category of the crime committed.") (quoting Furman v. Georgia, 408 U.S. 238, 402 (1972)).

52. See, e.g., McCleskey v. Kemp, 481 U.S. 279, 311 (1987) (stating that capital sentencing must focus on "the unique characteristics of a particular criminal defendant"); Kirkpatrick v. Blackburn, 777 F.2d 272, 286 (5th Cir. 1985) ("Before a state may impose the uniquely severe and irrevocable sentence of death, it must 'focus on the personal intent and culpability of the defendant himself ... . ") (quoting Reddix v. Thigpen, 728 F.2d 705, 708 (5th Cir. 1984)), cert. denied, 476 U.S. 1178 (1986); People v. Jimerson, 535 N.E.2d 889, 907 (IIl. 1989) ("Imposition of the death penalty requires, as a constitutional matter, an individualized consideration of both the offender's character and the circumstances of his offense."), cert. denied, 497 U.S. 1031 (1990).

53. See Penry v. Lynaugh, 492 U.S. 302 (1989); Thompson v. Oklahoma, 487 U.S. 815 (1988); Tison v. Arizona, 481 U.S. 137 (1987); Enmund v. Florida, 458 U.S. 782 (1982).

54. 458 U.S. 782 (1982).

55. Id. at 798 .

56. Id. at 800 . The Court found that the degree of the defendant's culpability in this instance was defined most sharply by his "intentions, expectations, and actions." Id.

57. Id. at 801 .

58. Id. at $798-801$. 
Five years after Enmund, however, in Tison v. Arizona, ${ }^{59}$ the Court revisited the issue of capital punishment for the non-triggerman in a felony murder case. In Tison, the Court abided by its previous determination that the defendant's actions and mens rea were the relevant factors defining the culpability of such defendants. Nevertheless, the majority concluded that the line originally drawn in Enmund had to be re-drawn. Although the factors affecting culpability had been correctly identified, the Court concluded that they had been incorrectly weighed. The Tison court found that non-triggermen felony murderers were eligible for the death penalty when they manifested a "reckless indifference to human life" and were heavily involved in the underlying felony offense. ${ }^{60}$ The Tison Court found that the Eighth Amendment did not require as high a level of intent and involvement as had previously been delineated in Enmund. Accordingly, the Court re-drew the line to bring it into conformity with the strictures of the culpability standard.

This scenario is not the only one in which the Supreme Court has identified a confluence of factors which together establish the level of the defendant's culpability. The Court also has explicitly identified multiple issues in its examination of the culpability of juvenile and mentally retarded defendants who are sentenced to death. Most important for the guilty but mentally ill defendants who are condemned to die, one of the factors recognized in these cases is volitional impairment.

\section{A. Volitional Impairment in Youth}

Over the years, the Court has struggled with the issue of whether a defendant's youthfulness may lead to such a diminished state of culpability that a sentence of death would violate the Eighth Amendment. This determination is complicated because age itself is not a defining trait that speaks directly to culpability. Rather, youthfulness serves as a proxy for two factors that are commonly found in young people and that do affect culpability: impaired volition and a diminished ability to plan. ${ }^{61}$ The issue is

59. 481 U.S. 137 (1987).

60. Id. at $137-38$.

61. Eddings v. Oklahoma, 455 U.S. 104, 115 n.11 (1982) ("Crimes committed by youths may be just as harmful to victins as those coinmitted by older persons, but they deserve less punishment because adolescents may have less capacity to control their con- 
further complicated because age serves as an imperfect proxy in determining culpability. Since some children mature at faster rates than others, children of the same age may differ vastly in their capacity "to control their conduct and to think in long-range terms." Consider, for example, the case of a youth who matures less quickly than his peers, but whose chronological age surpasses the age set by a bright-line test. This youth could be executed even though his culpability was insufficient as measured by his "capacity to control ... conduct" and his ability "to think in longrange terms"- the true indicators of culpability for Eighth Amendment purposes. Nevertheless, Eighth Amendment jurisprudence must accept the imperfect proxy of age as a constraint on the imposition of the death penalty. ${ }^{63}$

In Thompson v. Oklahoma, ${ }^{64}$ a plurality of the U.S. Supreme Court chose to draw a bright line at age sixteen. ${ }^{65}$ The plurality relied on the decreased capacity of adolescents to control their conduct as one of the two factors that evidenced insufficient culpability. ${ }^{66}$ Justice O'Connor joined the plurality's judgment because she believed that the defendant's sentence of death must be set aside, albeit on grounds other than insufficient culpability. ${ }^{67}$ Her refusal to join the plurality's opinion on culpability did not rest on a belief that this analysis was not required. On the contrary, Justice O'Connor agreed that "proportionality requires a nexus between the punishment imposed and the defendant's blameworthiness." Although she was willing to agree that "ado-

duct and to think in long-range terms than adults.") (quoting TWENTIETH CENTURY Fund TASK FORCE ON SENTENCING POLICY TOWARD YOUNG OFFENDERS, CONFRONTING YOUTH CRIME 7 (1978)).

62. Id.

63. Thompson v. Oklahoma, 487 U.S. 815,872 (1988) ("Doubtless at some age a line does exist-as it has always existed in the common law-below which a juvenile can never be considered fully responsible for murder.") (Scalia, J., dissenting) (citation omitted).

- 64. 487 U.S. 815 (1988).

65. "[W]e ... conclud[e] that the Eighth and Fourteenth Amendments prohibit the execution of a person who was under 16 years of age at the time of his or her offense." Id. at 838 (plurality opinion). Justice O'Connor concurred in the judgment and concluded that people "who were below the age of 16 at the time of their offense may not be executed under the authority of a capital punishment statute that specifies no minimum age." Id. at 857-58 (O'Connor, J., concurring in the judgment) (emphasis added).

66. Id. at $834-35$ (plurality opinion).

67. Id. at 853 (O'Connor, J., concurring in the judgment). ing)).

68. Id. (quoting Enmund v. Florida, 458 U.S. 782, 825 (1982) (O'Connor, J., dissent- 
lescents are generally less blameworthy than adults who commit similar crimes," she noted that "it does not necessarily follow that all 15-year-olds are incapable of the moral culpability that would justify the imposition of capital punishment." 69

\section{B. Volitional Impairment Among the Mentally Retarded}

The same concerns for imperfect proxies that Justice O'Connor expressed in Thompson are also evident in Penry $v$. Lynaugh, ${ }^{70}$ in which the Court addressed the imposition of capital punishment on the mentally retarded. Justice O'Connor, writing for the Court, examined the culpability of mentally retarded defendants as a class to determine whether the Eighth Amendment bars the use of the death penalty against them. ${ }^{71}$

In identifying the issues that are dispositive of culpability, Justice O'Connor recognized the same proxy problem that had existed in Thompson. That is, mental retardation is not itself a trait that bears directly on culpability; rather, it serves as a proxy for other factors. Justice O'Connor identified two issues that speak directly to culpability in the case of the mentally retarded: the capacity to control one's impulses and the ability to evaluate the consequences of one's conduct. ${ }^{72}$

After examining the class as a whole, Justice O'Connor was unable to conclude that mental retardation precludes capital punishment. She explained that "all mentally retarded people of [the defendant]'s ability [do not]-by virtue of their mental retardation alone, and apart from any individualized consideration of their personal responsibility-inevitably lack the cognitive, volitional, and moral capacity to act with the degree of culpability associated with the death penalty." 73 Although four Justices agreed that the culpability of the mentally retarded depended, in part, on their

69. Id.

70. 492 U.S. 302 (1989).

71. Id. at 319. "[P]unishment should be directly related to the personal culpability of the criminal defendant." Id. "Thus, the sentence imposed at the penalty stage should reflect a reasoned moral response to the defendant's background, character, and crime." Id. (quoting California v. Brown, 479 U.S. 538, 545 (1987) (O'Connor, J., concurring)).

72. Id. at 322. Justice O'Connor also identified a third factor-a history of childhood abuse. This factor, however, was personal to the background of the particular defendant in the case. It is not necessarily a defining trait of the class of mentally retarded defendants.

73. Id. at 338. 
volitional capacity, ${ }^{74}$ they disagreed with Justice O'Connor's determination that some members of the class of mentally retarded defendants may be sufficiently culpable to be put to death. ${ }^{75}$ The implication of the Penry decision is that the Eighth Amendment bars the imposition of the death penalty on mentally retarded people who are volitionally impaired to some greater degree than was the defendant in that case. ${ }^{76}$

\section{APPLICATION OF CULPABILITY ANALYSIS WHERE VOLITIONAL IMPAIRMENT IS THE SOLE FACTOR}

Reduced capacity to control one's conduct, in conjunction with other impairments, led a plurality of the Court to create a brightline rule against capital punishment in the age-based cases ${ }^{77}$ and appears to mandate a similar proscription against the death penalty for defendants who are mentally retarded to a degree that is still undetermined. ${ }^{78}$ The key question for the guilty but mentally ill defendant is whether impaired volitional capacity alone can justify the imposition of a bright-line rule. Thompson and Penry demonstrate that volitional impairment bears on culpability and reflect the long-accepted tenet that free will lies at the very foundation of our criminal justice system. Indeed, Justice Jackson characterized the "belief in freedom of the human will and a consequent ability ... to choose between good and evil" as "universal and persistent in mature systems of law."

On a theoretical level, "[i]t is felt to be impolitic and unjust to make a man answerable for harm, unless he might have chosen

74. Id. at 322. Justices Brennan, Marshall, Blackmun, and Stevens joined in this part of Justice O'Connor's opinion.

75. Id. at 344 (Brennan and Marshall, JJ., concurring in part and dissenting in part); id. at 350 (Stevens and Blackmun, JJ., concurring in part and dissenting in part).

76. Peter K.M. Chan, Note, Eighth Amendment-The Death Penally and the Mentally Retarded Criminal: Fairness, Culpability, and Death, 80 J. CRIM. L. \& CRIMINOLOGY 1211,1233 (1990) ("Note the wording of the ruling. The implication is that sentencing to death a criminal who is mentally retarded to a degree greater than Penry may be prohibited by the eighth amendment."); see also People v. Thompson, 785 P.2d 857, 888 (Cal. 1990) ("The Supreme Court held [in Penry] that mental retardation alone did not vitiate the need for individualized consideration of personal responsibility, and that some mentally retarded persons do not lack the cognitive, volitional or moral capacity to act with the degree of culpability associated with the death penalty.") (emphasis added), cert. denied, 498 U.S. 881 (1990).

77. See supra note 65 .

78. See supra note 76 and accompanying text.

79. Morissette v. United States, 342 U.S. 246, 250 (1952). 
otherwise." ${ }^{\text {"In }}$ most situations "the practical business of government and administration of the law [has been] obliged to proceed on more or less rough and ready judgments based on the assumption that mature and rational persons are in control of their own conduct." W1 When society recognizes that a person's free will has, been impaired, however, the law attempts to deal with that person in a humane way. ${ }^{82}$

In a number of instances, society has determined that a person's control over his actions may be so impaired that the individual should not be held accountable for the results of such actions. ${ }^{83}$ Such acts are classified as involuntary, and the "actor" is neither convicted nor punished. The question for the guilty but mentally ill defendant is whether a lack of culpability should prohibit imposition of the death penalty in light of society's recognition that the individual was unable to conform to the law's requirements. It is not debatable that impaired volition speaks directly to culpability. ${ }^{84}$ The question is whether the label of guilty but mentally ill is a species of volitional impairment that justifies an Eighth Amendment proscription.

\section{A. The Involuntariness Doctrine: Recognized Instances of Volition- al Impairment}

In determining how volitional impairment should affect the imposition of the death penalty, it is illuminating to examine other areas of the law-to ascertain what the concept of volition includes and to provide guidance in dealing with the legal effects of diminished volition. The American system of criminal law, for better or for worse, proceeds on the assumption that an individual's acts are voluntary and that individuals should be held responsible for their actions. However, since human experience indicates that acts are not always voluntary, the law provides exceptions to the voluntariness assumption. Insofar as the verdict of

80. Edwin R. Keedy, Insanity and Criminal Responsibility, 30 HARV. L. REV. 535, 546 n.38 (1917) (quoting OLIVER IV. HOLMES, JR., THE COMMON LAW 54 (1881)).

81. Gregg Cartage \& Storage Co. v. United States, 316 U.S. 74, 80 (1942).

82. State v. Johnson, 399 A.2d 469, 471 (R.I. 1979).

83. See infra Section III(A).

84. See supra Sections II(A)-(B); see also Skipper v. South Carolina, 476 U.S. 1, 13 (1986) (Powell, J., concurring) (stating that a defendant's capacity to make a considered choice in regard to his actions is a factor that is "central to the fundamental justice of execution"). 
guilty but mentally ill recognizes a diminished capacity to control . one's conduct, it is sufficiently akin to other recognized forms of volitional impairments that the Eighth Amendment should bar imposition of the death penalty in such cases.

Perhaps the most commonly recognized and deeply rooted exception to the assumption of voluntariness occurs when one individual applies physical force to another so as to directly cause the other to move. Obviously, the second individual should not be, and is not, held accountable for the results of his involuntary act. ${ }^{85}$ Matthew Hale outlined this archetypal scenario with the following example: "If there be an actual forcing of a man, as if $A$. by force take the arm of $B$, and the weapon in his hand, and therewith stabs $C$. whereof he dies, this is murder in $A$. but $B$. is not guilty." tary because of the blatancy of its involuntariness and, perhaps most importantly, because nearly everyone has experienced such an involuntary act-albeit not usually one resulting in a death. Indeed, this situation is so compellingly involuntary on its face that "such motion never has been viewed as action of the victim of the force." ${ }^{87}$ Instead, the action is attributed to the individual applying the force.

Although situations involving actual physical force are the most easily recognized category of involuntary acts, society has long accepted that, in other settings, people exhibit the same decreased capacity to control conduct that underlies the concept of

85. For example, the Model Penal Code provides in pertinent part:

(1) A person is not guilty of an offense unless his liability is based on conduct that includes a voluntary act or the omission to perform an act of which he is physically capable.

(2) The following are not voluntary acts within the meaning of this Section:

...

(d) a bodily movement that otherwise is not a product of the effort or determination of the actor, either conscious or habitual. MODEL PENAL CODE \& 2.01 (1985).

86. 1 Matthew Hale, The History of the Pleas of the CROWN 434 (Philadelphia, Robert H. Small 1847) (citation omitted); see also Martin v. State, 17 So. $2 \mathrm{~d}$ 427, 429 (Ala. Ct. App. 1944) ("[A]n accusation of drunkenness in a designated public place cannot be established by proof that the accused, while in an intoxicated condition, was imvoluntarily and forcibly carried to that place by the arresting officer."); State v. Boleyn, 328 So. 2d 95 (La. 1976) (reversing and remanding on the issue of voluntariness because the evidence indicated that the defendant was unconscious at the time of his escape from prison and that he was renoved without his consent).

87. MODEL PENAL CODE $\S 2.01 \mathrm{cmt}$. at 221 (1985) (footnote omitted). 
involuntariness. Unconsciousness is clearly such a category. ${ }^{88}$ The difficulty lies in the definition of unconsciousness. Caselaw has come to accept that acts attributable directly to an epileptic fugue-a type of unconsciousness-are involuntary and thus may not be punished. ${ }^{89}$ The courts have recognized that, as with the application of actual physical force, "[s]urely, there must be, in the case of the epileptic, a period of penumbra when the will is in a state of total or partial paralysis." ${ }^{.90}$ Similarly, homicides occurring during an attack of somnolentia or somnambulism ${ }^{91}$ are treated as involuntary acts because of their close rejation to unconsciousness. ${ }^{92}$ These cases reiterate that the key issue is not consciousness per se, but rather a legitimate impairment of ability to control one's actions.

\section{B. The Concept of Volitional Impairment}

Conceptually, volition is a complex issue because it does not exist in the same concrete way as do other elements of criminal law, such as acts. As a result, volition is most often defined through exclusion based on certain proxy situations. Society accepts, for example, that actual physical force, unconsciousness, and the intermediate state between sleep and wakefulness approximate volitional impairment closely enough to qualify as acceptable proxies for volitional impairment. These proxies themselves are not, however, the reason that the instances are classified as involuntary. Rather, they are merely evidence or symptoms of the underlying problem-a recognized inability to control one's conduct. ${ }^{93}$

88. Id. at 219 (1985).

89. See Government of the Virgin Islands v. Smith, 278 F.2d 169, 175 (3d Cir. 1960) (noting that "the operator of an automobile who is suddenly stricken by an illness which he had no reason to anticipate but which renders it impossible for him to control the car is not chargeable with negligence") (footnote omitted).

90. People v. Freeman, 142 P.2d 435, 439 (Cal. Dist. Ct. App. 1943); accord People v. Decina, 138 N.E.2d 799 (N.Y. 1956) (stating that a sudden epileptic attack, or other sudden and disabling attack, renders one non-culpable as to results that flow from that attack when one has no prior knowledge or warning of the condition).

91. Sornnolescent and somnambulistic hoinicides occur when "the accused produce[s] the harm during the period of semi-wakefulness immediately following sleep or during an episode of sleepwalking." Sanford J. Fox, Physical Disorder, Consciousness, and Criminal Liability, 63 COLUM. L. REV. 645, 653 (1963).

92. See Fain v. Coinmonwealth, $78 \mathrm{Ky} .183,193$ (1879) (stating that the law only punishes "overt acts done by responsible inoral agents" and indicating that somnolentia destroys such moral agency).

93. See MODEL PENAL CODE $\$ 2.01 \mathrm{cmt}$. at 215 (1985). 
When making the factual determination of whether an individual was unable to control his actions, society must rely on its accumulated experience to determine whether the asserted condition did in fact exist. Since we have all stepped on someone else's foot because of a shove from behind and "have all experienced dreams, and semi-waking not-fully-conscious states when the alarm continues to ring in the morning," ety, that such acts are not rightfully attributable to us as individuals. Instead, society labels such acts as involuntary because of our lack of control over them. In contrast, other claims of involuntariness seem less plausible to society. ${ }^{95}$ Accordingly, courts hesitate to recognize volitional impairment in the absence of societal acceptance of the explanation.

\section{APPLICATION OF THE CULPABILITY REQUIREMENT TO THE GUILTY BUT MENTALLY ILL DEFENDANT}

\section{A. Societal Recognition of Volitional Impairment}

In dealing with the issue of whether the label "guilty but mentally ill" necessarily implies a reduced level of culpability that should bar imposition of the death penalty, it is important to analyze the implications of this verdict step-by-step. The first question is whether society recognizes that a guilty but mentally ill defendant is volitionally impaired to some degree. ${ }^{96}$ In the cases

94. Norval Morris, Somnambulistic Homicide: Ghosts, Spiders, and North Koreans, 5 RES JUDiCATAE 29, 32 (1951).

95. "Cheerfully we accept lack of consciousness of action as proof of ... involuntar[iness] . . . but indignantly reject lack of ability to control an action of which the actor is conscious as a proof of the same thing. Perhaps it is that we don't believe that there is an 'irresistible impulse' ...." Id. at 32. Although this observation was made prior to the advent of guilty but mentally ill statutes, an examination of guilty but mentally ill cases reveals that this very disbelief in the existence of an irresistible impulse permeates the opinions. See, e.g., State v. Wilson, 413 S.E.2d 19, 23-24 (S.C.) ("[T]he irresistible impulse test is very difficult, if not impossible, to apply with accuracy. It has been suggested that it is impossible to say that an impulse was irresistible rather than unsuccessfully resisted, or to distinguish between the uncontrollable impulse and the impulse that is not controlled.") (citation omitted), cert. denied, 113 S. Ct. 137 (1992).

96. It is essential that society recognize volitional impairments before they are institutionalized in the law. Our criminal legal system proceeds on the assumption that human beings have free choice until this assumption is rebutted with a socictally recognized exception. For a general discussion of the historical development of distinctions in criminal culpability, see Paul H. Robinson, A Brief History of Distinctions in Criminal Culpability, 31 HASTINGS L.J. 815 (1980). Robinson points out that "the history of the common law tradition . . . may be recognized as reflecting a process of continuous develop- 
of application of actual physical force, unconsciousness, and semiwakefulness, society considers the fit between these proxies and the underlying rationale of loss of capacity to control actions to be sufficient to warrant the label of involuntariness. However, when society determines that the answer to one question-"Was the defendant in a state of semi-wakefulness at the time of his actions?"-is an appropriate substitute for the ultimate question-"Was the defendant able to control his actions?"--there is a risk that the correlation of the responses will be less than perfect. ${ }^{97}$ Such is not the case, however, with the class of guilty but mentally ill defendants who acted under an irresistible impulse arising out of their mental illnesses. For these defendants, there is no proxy involved; they are by definition volitionally impaired. ${ }^{98}$ A verdict of guilty but mentally ill is itself recognition of volitional impairment.

\section{B. Relation of Volitional Impairment to Culpability}

Having determined that society recognizes a claim of volitional impairment, the next step is to determine how that volitional impairment relates to the minimum level of culpability required for the imposition of capital punishment. In a number of death penalty cases, the U.S. Supreme Court has indicated that volition is a factor that inheres in the minimum level of culpability that must exist in order to execute a defendant. Indeed, the capacity of a defendant to make a considered choice is regarded as "central to the fundamental justice of execution." 99

The South Carolina Supreme Court has refused to acknowledge that the verdict of guilty but mentally ill has any necessary bearing on a defendant's culpability. ${ }^{100}$ U.S. Supreme Court pre-

ment and ... refinement of culpability distinctions." Id. at 821 . He notes that "[a] later generation may perceive additional fundamental distinctions in culpability and provide greater application of current ones. No doubt [however] the law should not and will not use distinctions beyond those that the [current] society considers significant." Id. at 853 .

97. When a semi-wakeful defendant, claiming the exculpatory benefit of the involuntariness doctrine, coinmits an act that he had the capacity to refrain from performing, that individual may wrongfully escape conviction due to the use of a proxy.

98. Mental illness is not a proxy. Rather, it is an attendant circumstance that must exist along with impaired volition in order for the defendant to be classified as "guilty but mentally ill." See infra note 107.

99. Skipper v. South Carolina, 476 U.S. 1, 13 (1986) (Powell, J., concurring).

100. State v. Wilson, 413 S.E.2d 19, 25 \& n.6 (S.C.), cert. denied, 113 S. Ct. 137 (1992). 
cedent, however, is to the contrary and clearly points to a correlation between volitional impairment and reduced culpability. In Thompson v. Oklahoma, ${ }^{101}$ for example, the U.S. Supreme Court identified the "less[ened] capacity [of adolescents] to control their conduct" as one of two factors evidencing the reduced culpability of juvenile defendants. ${ }^{102}$ The presence of this reduced culpability led a plurality of the Court to draw a bright line in age-based death penalty cases.

Although it is clear that impaired volition has an impact on culpability, the Court has not definitively articulated how severe the impairment must be to justify an Eighth Amendment proscription against execution. Based on Penry v. Lynaugh, ${ }^{103}$ it appears that a class of persons may be characterized by some volitional impairment that itself does not rise to a level sufficient to trigger an Eighth Amendment bar. $^{104}$ Taken together, Thompson and Penry indicate that, to support the drawing of a bright line based on diminished culpability, not only must a volitional impairment exist, but it must also exceed some threshold level. It was Justice O'Connor's inability to conclude that this threshold had been reached that prevented the Court from drawing a bright line in the context of mentally retarded defendants. ${ }^{105}$

\section{Effect of the Guilty but Mentally Ill Verdict on Culpability}

Since a finding of volitional impairment does not automatically give rise to a bar against capital punishment, the final step of the culpability analysis is to ascertain whether the volitional impairment indicates a level of culpability that is insufficient to support a sentence of death. If it does, then the verdict of guilty but mentally ill mandates a prohibition against the application of capital punishment. At this point, it is helpful to distinguish between the various meanings of the label "guilty but mentally ill" in the different states. ${ }^{106}$ Roughly speaking, there are two categories of

101. 487 U.S. 815 (1988).

102. Id. at 834-35 (quoting Eddings v. Oklahoma, 455 U.S. 104, 115 n.11 (1982)).

103. 492 U.S. 302 (1989).

104. In Penry, Justice O'Connor recognized that the class of mentally retarded defendants was characterized by a lessened ability to control impulses. Id. at 322-23. The Court, however, did not believe that the defendant's volitional impairment was so severe as to fall within the prohibitions of the Eighth Amendment.

105. Id. at 338.

106. See generally Bradley D. McGraw et al., The "Guilty but Mentally Ill" Plea and 
guilty but mentally ill statutes. In the first, the label connotes an inability to control one's actions, i.e., the presence of an irresistible impulse. ${ }^{107}$ In the second category, the label of "guilty but mentally ill" can attach when the impulse is less controlling. ${ }^{108}$

1. Irresistible Impulses. As to the first class of defendants-those who are found to be unable to control their actions-their volitional impairment rises to the level of involuntariness. Their degree of volitional impairment is so great that their actions cannot be rightfully attributed to them. Instead, society has conceded that these defendants were deprived of the ability to control their conduct because of a mental disease or defect. The defendant who is found to lack the capacity to control his actions because of a mental illness, like the epileptic who cannot control movements because of a seizure, should not be held personally accountable for acts resulting from his illness. ${ }^{109}$ Rather, these

Verdict: Current State of the Knowledge, 30 VILL. L. Rev. 117, 128-29 (1985) (outlining the standards and definitions of guilty but mentally ill and insanity in the twelve states that have guilty but mentally ill statutes).

107. Such is the case for the guilty but mentally ill defendant who is convicted in the state of South Carolina. The state statute provides: "A defendant is guilty but mentally ill if, at the time of the commission of the act constituting the offense, . . because of mental disease or defect he lacked sufficient capacity to conform his conduct to the requirements of the law." S.C. CODE ANN. \& 17-24-20(A) (Law. Co-op. Supp. 1992).

108. For example, in Illinois, a defendant "who, at the time of the commission of a criminal offense, was not insane but was suffering from a mental illness . . may be found guilty but mentally ill." ILL. COMP. STAT. ANN. ch. 720, \& 5/6-2(c) (West 1993). The Illinois guilty but mentally ill statute defines mental illness as "a substantial disorder of thought, mood, or behavior which afflicted a person at the time of the commission of the offense and which impaired that person's judgment, but not to the extent that he ... [was] unable to conform his conduct to the requirements of law." Id. § 5/6-2(d); see also IND. CODE ANN. \& 35-36-1-1 (Burns 1985) (indicating that guilty but mentally ill individuals are those who have psychiatric disorders that impair ability to function); N.M. STÁT. ANN. \$31-9-3A (Michie 1984) (indicating that guilty but mentally ill individuals are those who have substantial disorders that impair judgment, but not to the extent that they cannot prevent themselves from acting).

109. In Thompson, Justice O'Connor stated that "it does not necessarily follow [from youth itself] that all 15-year-olds are incapable of the moral culpability that would justify the imposition of capital punishment" in light of the fact that characteristics "vary widely among different individuals of the same age." Thompson v. Oklahoma, 487 U.S. 815, 853-54 (1988) (O'Connor, J., concurring). Likewise, in Penry, Justice O'Connor could not "conclude that all mentally retarded people of Penry's ability ... inevitably lack the cognitive, volitional, and moral capacity to act with the degree of culpability associated with the death penalty." Penry, 492 U.S. at 338. The factual problems that concerned Justice O'Connor in Thompson and Penry are not present in the case of guilty but mentally ill defendants who act pursuant to an irresistible impulse. Before a defendant can be 
acts should be attributed to the mental illness and classified as involuntary. ${ }^{110}$

The Supreme Court of Delaware touched on this logic when it noted that the difference "between an involuntary act and an act caused by inental illness is, perhaps, a somewhat metaphysical one."111 A state is not required to recognize that mental illness causes some actions to be involuntary. ${ }^{112}$ When a state does recognize such a relationship, however, executing those who acted because of their mental illness allows imposition of the death penalty to turn on a metaphysical distinction. Because the death penalty is severe and irrevocable, its imposition should not be made to turn on such word games. If society is willing to recognize that an individual did not have control over his actions, that factual determination must control the outcome, not the label-"guilty but mentally ill" versus "involuntary act"-applied to it. Acknowledging a defendant's inability to control his actions mandates a proscription against the death penalty. ${ }^{13}$

found to be guilty but mentally ill in a state where the verdict indicates an irresistible impulse, there must be a factual finding that the individual had insufficient capacity to conform to the requirements of the law. See, e.g., supra note 107.

110. See Keedy, supra note 80 , at 548 ("It is difficult to see, from an abstract consideration of the question, why courts should have refused to recognize irresistible impulse as a defense, when it so clearly negatives a necessary element of crime, and when they without hesitation recognized other manifestations of lack of volition."). $C f$. Sentence of Bancroft, 3 Crim. App. (S.) 119, 120 (1981) (U.K.) ("[T]here is still in every human being a residual capacity for self-control, which the exigencies of a given situation may call for. That must be the justification for passing a sentence of imprisonment, to recognize that there is still left some degree of culpability . . ..").

111. Sanders v. State, 585 A.2d 117, 130 (Del. 1990) (emphasis added).

112. State v. Korell, 690 P.2d 992, 998-1000 (Mont. 1984).

113. Other cases involving the imposition of the death penalty on guilty but mentally ill defendants have intimated that the defendant must have the capacity to conform to the law before such a penalty may be imposed. See, e.g., Sanders, 585 A.2d at 134 (stating that ability to resist pathological impulses "provides a justification for punishment"). A proscription against the death penalty inheres in the well-accepted tenet that one cannot be convicted for involuntary acts. See Powell v. Texas, 392 U.S. 514, 534 (1968) (intimating that a state could not convict for murder a defendant who suffered from an overpowering compulsion to kill); supra Section III(A). In South Carolina, a judge must make a finding on the record that a defendant "lacked sufficient capacity to conform his conduct to the requirements of the law" before that defendant may be found to be guilty but mentally ill. S.C. CODE ANN. \& 17-24-20(D) (Law. Co-op. Supp. 1992). Such a finding, however, should bar not only execution but also conviction itself under the rationale of Powell. See MOdel Penal CODE § 2.01, cmt. 1 at 215 (1985) ("People whose involuntary movements threaten harm to others may present a public health or safety problem, calling for therapy or even for custodial commitment; they do not [however] present a problem of correction."). 
2. Substantial Impairment. The second class of guilty but mentally ill defendants consists of those who act under an impairment that, although substantial, does not destroy their ability to conform their conduct to the requirements of the law. ${ }^{114}$ For these defendants, it is less clear whether the verdict of guilty but mentally ill necessarily imports a level of volitional impairment that justifies a bright-line proscription of the death penalty. Proponents of the position that such defendants should be death-eligible point out that these individuals were not robbed of all their volitional capacity. ${ }^{115}$ As the argument goes, these defendants' impulses are not unlike those created by poverty, lack of education, or other societal pressures that may constrain a person in his ability to act freely. ${ }^{116}$

Although it is true that guilty but mentally ill defendants, like those who are the product of disadvantaged backgrounds, retain at least a theoretical ability to conform to the strictures of the law, there is one key distinction. Society has chosen to take statutory notice of impulses arising out of mental illness. It is also critical to note that society did not choose to categorize this volitional impairment as a mere factor to be considered in sentencing. Rather, it has recoguized the need to qualify the verdict itself.

\section{CONCLUSION}

The acknowledgment that a person may be guilty but volitionally impaired speaks directly to the assumptions underpinning the American criminal justice system. Insofar as free will is a predicate assumption of our legal system, any legal recognition of the invalidity of that assumption in certain circumstances, when coupled with a death sentence, raises profound questions. ${ }^{117}$ In-

114. See supra note 108.

115. See, e.g., Sanders, 585 A.2d at 134. ("The fact that [a guilty but mentally ill defendant] might, in theory, have resisted his pathological impulses provides a justification for punishment.").

116. See, e.g., California v. Brown, 479 U.S. 538, 545 (1987) (O'Connor, J., concurring) (noting the belief long held by society that an individual's background may affect his degree of culpability).

117. In drawing a bright line against the execution of young murderers, the plurality observed that society's creation of a juvenile court system reflected on the criminal responsibility of children, even those convicted in the adult criminal system. The Court noted that the existence of this institution clearly implied "an absence of the basis for 
voluntariness derives its exculpatory force not from some talismanic quality inhering in the label but rather from the societal recognition of the absence of volition. Because of the statutory recognition of substantially impaired volitional capacity, guilty but mentally ill defendants differ merely in degree, not in kind, from those who successfully raise the defense of involuntariness. Accordingly, it is curious indeed that courts have clung so religiously to a black-and-white view of volition.

An understanding of the underlying reasons for the enactment of guilty but mentally ill statutes provides insight into this paradox. "[A]s a general proposition, [these] statutes were created in part to narrow the field of defendants who could successfully claim a lack of culpability via the insanity defense."118 These laws were legislative responses to a popular perception that too often people were "beating the system" through use of the insanity defense. ${ }^{119}$ Whether this perception is accurate is, at some level, immaterial. The punishment of those who cause harm to society strengthens the social fabric. Guilty but mentally ill legislation was, in large part, an effort to shore up social cohesion in the face of perceived abuses of the legal system. ${ }^{120}$

Although society may find it expedient to lower its standards for conviction purposes to strengthen social cohesion, the question of the appropriate level of punishment remains. Thus far, courts have avoided addressing this issue directly. The South Carolina Supreme Court, for example, examined the irresistible impulse test im the insanity context and determined that it is a test that "is

adult criminal accountability-the exercise of an unfettered free will." Thompson v. Oklahoma, 487 U.S. 815, 835 n.41 (1988) (plurality opinion) (quoting SANFORD J. Fox, THE JUVENILE COURT: ITS CONTEXT, PROBLEMS AND OPPORTUNITIES 11-12 (1967)).

118. State v. Wilson, 413 S.E.2d 19, 22 (S.C.), 'cert. denied, 113 S. C. 137 (1992).

119. See McGraw et al., supra note 106, at 124-25 (stating that the acquittal on insanity grounds of John W. Hinckley, Jr. for the shooting of President Ronald Reagan prompted the passage of many guilty but mentally ill statutes).

120. On the issue of social cohesion, H.L.A. Hart said,

Punishing the offender is required to maintain social cohesion because the common conscience, violated by the offence, "would necessarily lose its energy if an emotional reaction of the community [in the form of punishment] did not come to compensate its loss, and it would result in a breakdown of social solidarity."

H.L.A. Hart, Social Solidarity and the Enforcement of Morality, 35 U. CHI. L. REV. 1, 7 (1967) (quoting EMILE DURKHEIM, THE DIVISION OF LABOUR IN SOCIETY 90 (George Simpson trans., 3d ed. 1964)) (alteration in original); see Gregg v. Georgia, 428 U.S. 153, 183 (1976) (plurality opinion) (stating that the death penalty "is essential in an ordered society that asks its citizens to rely on legal processes rather than self-help to vindicate their wrongs"). 
very difficult, if not impossible, to apply with accuracy."121 If South Carolina truly does find the irresistible impulse test an "impossible standard" to apply with accuracy, judicial integrity demands that the court not masquerade guilty verdicts under the label "guilty but mentally ill." 122 Notwithstanding the South Carolina Supreme Court's assertions to the contrary, ${ }^{123}$ there is a qualitative difference between a verdict of guilty and a verdict of guilty but mentally ill. Failure to import this difference from the judgment stage to the sentencing stage is irreconcilable with the Eighth Amendment's demand that punishment be a moral and reasoned response to the culpability of the individual. Permitting the execution of those whom society acknowledges to have been volitionally impaired does not enhance an individual's responsibility for his behavior. Rather, it diminishes the value of punishment. ${ }^{124}$

Although society may find it beneficial to convict a defendant for a crime while simultaneously recognizing diminished volition, the Eighth Amendment should bar society from imposing a sentence of death on such an individual. The death penalty is the ultimate expression of society's rage and the most exacting penalty that may be inflicted under the American system of justice. As such, its imposition has been tempered by the Eighth Amendment through the culpability requirement. At its base, capital punishment presupposes "the existence of a fully rational, choosing agent." 125 Admitting that a mentally ill defendant was even somewhat volitionally impaired while simultaneously insisting that such a defendant is deserving of the harshest retribution that society can exact makes a mockery of the spirit of the prohibition against cruel and unusual punishment. ${ }^{126}$ Accordingly, official

121. Wilson, 413 S.E.2d at 23-24.

122. See id. at 25 (stating that a defendant who acts pursuant to an irresistible impulse "is guilty, albeit 'guilty but mentally ill" ").

123. Id. at 24-25.

124. Jean Dabin, a natural law theorist, asks, "Can one conceive of the public good turning its back on natural law and justice?" He contends that "while altogether distinct from natural law and justice, [the public good] cannot fail to have close ties to [them]." JEAN DABIN, GENERAL THEORY OF LAW (1944), reprinted in LEGAL PHILOSOPHIES OF LASK, RABRUCH AND DABIN 416 (Kurt Wilk trans., 1950).

125. Thompson v. Oklahoma, 487 U.S. 815,825 n.23 (1988) (plurality opinion) (emphasis added).

126. Because a sentence of death is qualitatively different from a jail sentence, "there is a corresponding difference in the need for reliability in the determination that death is 
recognition of volitional impairment must bar capital punishment for guilty but mentally ill defendants "to protect the dignity of society itself from the barbarity of exacting mindless vengeance." 127 